\title{
CORRESPONDENCE
}

\author{
POTASSIUM-ARGON AGE STUDIES IN SCOTLAND
}

Sir,-We refer to the letter by Dr. T. E. Smith criticizing our paper " $\mathrm{K}-\mathrm{Ar}$ age studies in Scotland". When Dr. Smith was kind enough to forward the samples from localities 17 and 18, Table $2(a)$, they were referred to, by him, as "Central Highland Granulite (Moine-Monadleath)". Dr. Smith states that one of these specimens was affected by migmatization and comments on the importance of this with respect to dating migmatization in the Moine and Dalradian areas. We thank Dr. Smith for his correction of the nomenclature but we do not believe that the interpretation of the age pattern is significantly affected by the specimens being either Moine or Dalradian. This is because in the Central Highland area both the Moine and Dalradian rocks have been affected by events which post-date the main post- $\mathrm{F}_{2}$ metamorphism and migmatization, and this is demonstrable on both radiometric and geological evidence. The ages of 432 and 427 million years on specimens 17 and 18 respectively, do not reflect the main (or post- $\mathrm{F}_{2}$ ) metamorphism but these later events (P. E. Brown, J. A. Miller, N. J. Soper, and D. York, 1965. Proc. Yorks., Geol. Soc., 35, 103-138).

With regard to the granitic rocks from the Strath Spey Complex (Table 2d, p. 117) our opinion on the position of these rocks was stated on page 120 . We did not regard these rocks as being of metamorphic origin but considered that they were associated (in time) with the third phase $\left(\mathrm{F}_{3}\right)$ metamorphism. To distinguish these granitic rocks with ages some 20 million years greater than typical Newer Granites ( 400 million years) we placed them in a separate table $(2 d)$ headed "Older" Granitic Rocks from the Loch Laggan Area. Association with the Dalradian migmatites of MP2 age was not stated or intended, but in view of the evident possiblility of confusion introduced by using the term "Older" we agree that the heading of the table was perhaps unfortunate. There now seems to be a group of granite intrusions, in which the Strath Spey Complex may possibly be included, previously classed as New Granites, but which yield significantly greater ages (P. E. Brown, J. A. Miller, R. L. Grasty, and W. E. Fraser, 1965, Nature, 207, 1287-8).

The Dalchully granite with an age of 393 million years (Table 4, locality 72) must be separated on radiometric grounds from those granites with ages of 420 million years or greater, as must also the Allt Crom Granite with an age of 404 million years (Table 4 , locality 71 ).

DePaRTMENT OF GeOlogy,

P. E. Brown.

UNIVERSITY OF SHEFFIELD.

Department of Geodesy and Geophysics,

J. A. Miller.

UNIVERSITY OF CAMBRIDGE.

4th October, 1965.

\section{THE GRAPTOLITIC MUDSTONES OF THE HOWGILL FELLS}

SIR,-Dr. Llewellyn's comments (Geol. Mag., 102, pp. 277-8) on my paper are welcome, and I look forward to the detail of his published results. I agree that the Wenlock strata of the Lake District proper may be precisely described as "graptolitic, argillaceous siltstones": but the generally finer-grained rocks of the Howgill Fells may, with equal precision, be described as graptolitic mudstones. 
His comments of paragraph 4 do not appear to be very constructive, since in my paper I attempted to explain the part played by benthonic animals. However, it is of interest that those horizons where Dr. Llewellyn would expect less benthonic activity (that is, where the sedimentation rate is greatest : see his paras. 5 and 6) are in fact typified by an increase in both number and variety of bottom-working organisms. I have not "invoked " a destruction of carbonaceous banding, but simply recorded that banding is destroyed in many instances to produce a homogeneous medium-dark grey mudstone.

Dr. Llewellyn's remark (para. 3) "There seems to be no reason at all to suppose that an extensively churned and pelleted sediment should not be subsequently burrowed by worms ..." is certainly valid. My main aim was to show that wherever indisputable evidence of reworking occurred, then the banding was destroyed. I maintain, however, that the faecal peliet concept is disputable. In the original detailed description of such " pellets "Cummins (1959 p. 163) pointed out that " ... the lenticles must have been more nearly equidimensional in the original sediment, and the lamination correspondingly less pronounced". In the primary calcareous nodules, through which the laminations pass, delicate graptolite rhabdosomes are preserved undistorted and in full relief, whilst on the same bedding planes only a few centimetres away from the nodules the same graptolite species are quite flattened. The calcareous nodules clearly afford the best medium for examining the "pellets" or "lenticles" in their original form.

Thin sections of the banding in such nodules show that the " pellets" do not exist. The rock is composed of an essentially ungraded mass of muddy, and at some horizons silty, material. There are no discrete bands of carbonaceous material, but merely irregularly-positioned flakes and patches caught up by the settling mud. It is only upon diagenetic compaction of the noncalcareous sediment (which may reduce the original thickness by more than 40 per cent) that flakes of carbonaceous matter become roughly orientated parallel to the bedding plane, and together with the natural inconsistencies present in an ungraded mud, result in a rock which is superficially lenticular. It is interesting to note that some of the so-called lenses, lenticles, or pellets exhibit grading. Frankly I find it difficult to believe that any bottom-working creature is capable of grading the contents of its faecal pellets.

There are other objections to the faecal pellet concept: the fact that " pelleted" beds, where they alternate with other rock types, are very sharply defined both at the top and bottom without any traces of working of the sediment : the fact that the most delicate plectograptids are not destroyed by the supposed benthonic activity : that an identical "pelleting" can be found, like the graptolites with which they are invariably associated, in a variety of facies-greywacke, grit, mudstone, even limestone : that a bottom-working creature could exist throughout the Ordovician and Silurian and probably longer, and yet leave no trace of itself except for millions upon millions of faecal pellets; a creature, moreover, which can ingest a variety of sediment types and produce faecal pellets the size of which are directly proportional to the grain size of the mud consumed.

I consider that the textures and composition of the mud (or silt) are quite in accordance with deposition by low density, turbid currents which caught up and enclosed slowly sinking carbonaceous matter and graptolite rhabdosomes. The faecal pellet concept is unnecessary.

\section{REFERENCE}

Cummins, W. A. 1959. The Nantglyn Flags ; Mid-Salopian Facies in Wales. Lpool. and Manchr. geol. J., 2, 159-167.

R. B. RickardS.

SEDGWICK Museum,

CAMBridge.

4th October, 1965. 